\title{
SPECIALIZED MEDICAL INFORMATION SPACE: HISTORY AND PRINCIPLES OF FORMATION
}

\author{
Sadivnychyi V. O.
}

\section{INTRODUCTION}

During actively scientists' exploring the different spheres of multitude databases, movement of information flows and structural elements of the information space, there is a classic idea that the information space is the environment in which information is produced and rotated and interaction in the process of common activity takes place. It's a collection of information, information infrastructure and subjects that collect, generate, disseminate and use information. Also it's a collection of information resources, a territory of information dissemination. In this work, the notion of information will be understood as a space that consists of information of different levels intended for its transmission to consumers.

The main structural components of the information space are information spheres and information flows. The information sphere is the totality of all concentrated in space information, regardless of its form and state, where "not physical, but logical-algorithmic information laws operate" . Information flow is "a collection of information that moves in the information space through communication channels. Information flows can flow both within and between individual infospheres, depending on the availability of communication channels"2.

Society's need in information has long been both widespread and differentiated. Differentiation is primarily about the desire to satisfy

${ }^{1}$ Кононович В. Г. Визначення інформаційного поля 3 позицій інформаційної безпеки. “АВIA-2011”: Матеріали X міжнародної науково-технічної конференції. Секція 2 - Інформачійна безпека. Київ : НАУ, 2011. Ст. 2.37.

2 Плескач В. Л., Затоноцька Т. Г. Інформаційні системи і технології на підприємствах : підручн. Київ : Знання, 2011. 718 с. URL: http://pidruchniki.com/ 1350052747708/informatika/ponyattya_informatsiynogo_prostoru (дата звернення: 15.02.2020). 
information interests related to more or less specialized knowledge: from the elemental desire to know (to take an umbrella or to leave it at home), to the desire to use freely complex household or professional appliances.

The professionals need the relevant content information, which is specialized, for orientation in professional activity, first of all, for solving problem situations and generating new knowledge in the chosen sphere.

In general, human, as a biological creature, constantly adapts the body to existing conditions, struggling for survival. And any topics become minor as soon as a health or life-threatening problems arise. In such extreme situations, human actions, as social creature, are based on knowledge, gained either in the course of the society development or at the time of the threat of life or health. And in this case the basic information becomes specialized, namely medical: the need for the population to obtain and understand information about health, illness, their prevention and treatment are caused by an elementary instinct for self-preservation.

The segment of specialized medical information in the information space was gradually filling: from drawings of the human body to the first printed and electronic anatomical tables; from the cuneiform text of Mesopotamia to the reproduction of printing and electronic classification of diseases; from the system of medicine, shamanism, hairdressing through the first medical faculties opening in the XII century to the current world system of training medical workers; from an introduction the first specialized books of medical history in the XIV-XV centuries to the present international unity of methodological approaches of clinical materials recording and comparison.

Scientific medicine in the second half of the XIX century was formed into a significant specialized segment of the information space from the beginning of its birth, dating to VI. B.C. (thanks to the accumulated information about human anatomy and physiology, diagnosis and treatment). The components of this segment have changed, new principles of dissemination, processing and storage of information have emerged and the existing principles have been improved.

The development of medicine is also closely linked to scientific exchange, from its first intuitive ideas to formation in the scientific 
knowledge system, from the advent of books and then periodicals, which took over the functions of disseminating new information and its promoting. The works on various problems of medicine were published in scientific journals of the general profile by the second half of the XVII century. One of these is "Journal des sçavans" (Paris, 1655-1792), which published papers about brain anatomy, pharyngeal muscles, and other spheres of medicine. The first special medical journal is "Nouvelles descouvertes sur toutes les parties de la médecine" (1679-1681), published by a Paris surgeon Nikola Blégny. More than 170 medical journals and periodical scientific papers in medicine were published in the beginning of the XVIII century according to encyclopedic data ${ }^{3}$.

\section{Socio-communicative parameters of the medical press}

Over time, the medical media found its place in the social communication system, gaining own readership. The community of significant attributes, which include technological, classroom, informational, functional, organizational and editorial, gives the grounds to position specialized medical periodicals and continuing editions as a single typological group.

We were based on several significant approaches concerning a selecting these editions and introducing them as an object in the sphere of social communication sciences.

The first of these approaches concerned the definition of the medicine concept and its distribution by spheres. This word comes from the Latin "medicina" - medicinal, therapeutic. It is defined as the set or cycle of the sciences about disease and health, treatment and prevention, health, the art of its preserving, and also the search for healing methods; as a system of scientific knowledge and practical actions united by one purpose - to recognize or diagnose diseases. The following definition is most commonly repeated in various sources: "Medicine is a system of scientific knowledge and practice which aims are promoting and preserving health, extending human life, preventing and treating human disease"4. Health in

3 Медицинская периодическкая печать. Большая медицинская энцุиклопедия Москва : Советская энциклопедия, 1980. Т. 14. Ст. 377.

4 Медицина. Большая медицинская энциклопедия. Москва : Советская энциклопедия, 1980. Т. 14. СТ. 3. 
scientific sources is defined as "the condition of optimal vital activity, which ensures the full realization of its essence" 5 .

And if humane medicine deals with human health, then veterinary medicine covers the system of biomedical sciences and practical actions for the prevention and treatment of animal diseases. The interconnection of medicine is inextricable and intended, primarily, to protect people from socalled zooanthroponosis - a disease that is transmitted in different ways from humans to animals.

Homeopathy is considered to be a kind of "therapeutic system, which originated on the principle of disease control drugs that cause in healthy person phenomena similar to the symptoms of the disease" 6 (from the Greek. Homoios - similar; pathos - suffering, illness). This treatment is based on the principle of "similar to similar". The founder is German doctor Samuel Hahnemann (1755-1843).

The human health system is also targeted at a food system in which people don't consume animal products - vegetarian.

We also proceeded with the statement that medicine as a system combines "theoretical, experimental, clinical and prophylactic components. Theoretical medicine is based on the basic sciences (biology, physics, chemistry, mathematics, psychology, sociology). The theory of anthropogenesis, the theory of norms, the theory of pathology can be highlighted as its basic components. Experimental medicine combines the research method theory, the experiment theory, the modeling theory, the results prediction theory. Clinical medicine includes the theory of human personality, the theory of diagnostics, the theory of treatment (psychosomatic optimization), the theory of rehabilitation, the theory of values. Preventive medicine includes the theory of hygiene, the theory of anthropoecology, the theory of prevention, the theory of health care" 7 .

The socio-communicative mechanism of medical information is based on the system of specialized knowledge dissemination in the information

${ }^{5}$ Соціально-філософські та етичні проблеми медицини : навч. посіб. ; за заг. ред. А. П. Алексеєнко, В. М. Лісового. Харків : Колегіум, 2010. Ст. 25.

6 Гомеопатия. Больщая медицинская энцңиклопедия. - Москва : Советская энциклопедия, 1977. Т. 6. Ст. 307.

${ }^{7}$ Соціально-філософські та етичні проблеми медицини : навч. посіб. ; за заг. ред. А. П. Алексеєнко, В. М. Лісового. Харків : Колегіум, 2010. Ст. 17-18. 
space. The distribution system included closed and open channels: private and official correspondence, exchange of scientific papers, documents dissemination of scientific and practical content, promulgation of the scientific researches results or practical observations at conferences, congresses, meetings, preparation of research descriptions for publication, publication of materials in periodicals, preparation for printing and reproduction of books and brochures, formation of specialized medical libraries, etc.

Scientific empirical and theoretical, scientific-practical, practical and other knowledge in medicine formed a separate segment in the information space.

The specialized medical information space "is an environment that provides the production, collecting, storage and distribution of the thoroughly tested, documented, accurate, accessible, valid information of medical and biological content, that gives the opportunity of information interexchange for agents in order to meet their information needs, providing epidemiological studies, statistical measurement, treatment and prevention or scientific research",

The main focus of the specialized medical information space is to address the challenges of the institutional health care system by ensuring the communicative functions of the area.

The second significant approach is related to the distribution of editions on periodicals and continuing, magazines, newspapers, sheets, and books.

According to the standard, the periodical is "an edition that is published at regular intervals, has a predetermined constant annual number and the name of numbered or dated, uniquely designed issues that are not repeated in content". And the continuing edition is "an edition that is published at indefinite intervals, as the material accumulates, numbered and (or) dated issues, unrepeatable in content, uniquely designed, with a common name". The main type of periodical media is the newspaper -

${ }^{8}$ Садівничий В. О. Становлення вітчизняного інформаційного простору в сегменті медичної преси наддніпрянської україни XIX - початку XX століть: типологія, функціонально-змістові особливості, комунікативно-прагматичні складники : дис. ... д-ра наук із соц. комунік : 27.00.04. Київ, 2015. 481 с. Ст. 23. 
"an edition with a permanent name, published in certain, short periods of time, contains official documents, operational information and materials on topical socio-political, scientific, industrial and other issues, and also literary works, photographs and advertising".

As a periodical and continuing edition, the magazine is a "periodical, which is published with a permanent name, has permanent columns, and contains articles, abstracts, other materials on various socio-political, scientific, industrial and other issues, literary works, illustrations, photographs"9.

As a media, magazine "has the following features: infinity and regularity of publication of numbers at certain intervals, published materials in the form of articles, ... a certain thematic direction of contents, ... special printing design, ... a permanent editorial board" $"$.

We selected the editions for analysis by these approaches, grouping them into specialized medical periodicals and continuing editions.

We started from the fact that specialized medical periodicals and continuing editions are "a special type of mass media with its problematic and thematic direction, internal structure, and clear auditorium"11.

\section{Specialized medical information space: main features}

The specialized medical information space of Naddniprianshchyna in the second half of the XIX - beginning of the XX centuries characterized by the development of social institutions (higher education institutions, scientific and other societies, research organizations, medical institutions); richness of the generated and reproductive medical knowledge; professional communication agents (medical scientists, medical practitioners and clinicians, nursing staff, students); corporate using; a community of typological features whose properties are defined by information infrastructure; the fact that there are specialized medical periodicals and continuing editions.

${ }^{9}$ ДСТУ 7152:2010. Видання. Основні види: Терміни та визначення. [Чинний від 1996-01-01]. Вид. офіц. Київ, 1995. 48 с. (Інформація та документація). Ст. 10, 12, 16.

${ }^{10}$ Семистяга Т. Видавничо-поліграфічна галузь України: динаміка й проблеми розвитку (2002-2004 роки). Друкарство. 2005. № 2. Ст. 7.

${ }^{11}$ Садівничий В. “Відродження розпочинається із гласності...” : (Медична преса Наддніпрянської України середини XIX - початку XX ст.) : монографія. Дніпропетровськ : Середняк Т. К., 2015. Ст. 83. 
In the period from 1860 to 1920 (chronological boundaries caused by the development of socio-political events), 186 specialized medical periodicals and continuing editions were published in 9 provinces of Naddniprianshchyna (Volyn, Katerynoslav, Kyiv, Podil, Poltava, Tavriy, Kharkiv, Kherson, Chernihiv).

Our calculations are based on the following analysis: a) catalogs of leading library institutions: Vernadskyi National Library of Ukraine, National Academy of Sciences of Ukraine, National Scientific Medical Library of Ukraine, Kharkiv Korolenko State Scientific Library, Odesa National Scientific Library, Russian National Library (St. Petersburg); b) catalogs of libraries of former provincial centers, departmental and higher educational institutions; c) recorded data from scientific and bibliographic sources, etc. We have identified a number of editions in only one copy and only in one of the libraries. The bibliographic catalogs and indexes of the retrospective plan were a considerable array of research sources. Historical and bibliographical works and catalogs, organized by creative scientific teams, were of great importance.

The analysis made it possible to state that specialized medical periodicals and continuing editions of Naddniprianshchyna were published in 26 cities. Most of these editions - 52 - were recorded in Kyiv, 35 were published in Odesa, 34 - in Kharkiv. Further indicators are significantly decreasing and are: Katerynoslav - 12 editions, Simferopol - 10, Kherson - 8, Zhytomyr and Poltava - 6, Kamianets-Podilskyi and Yalta - 5, Chernihiv - 4, Kremenchuk - 2, Balaklava, Vinnytsia, Yelysavetgrad, Kerch, Myrhorod, Sevastopol, Sloviansk, Feodosia, Khorol, Khorol - 1 . The complete list of cities and the number of editions is given in table 1 .

In those cities of Naddniprianshchyna, where there were medical faculties at universities in the XIX - early XX centuries, the specialized information sphere is much more saturated than in others, even in the provincial centers to which Kherson, Simferopol, Poltava, Chernihiv, Katerynoslav belonged. Although the number of practitioners in these cities is not inferior to university cities: "most of the doctors were in the service in Poltava county - 95 people. In... Kharkiv, Kherson and 
Chernihiv governments their number ranged from 78 to 62 people in the province" 12 .

Table 1

List of cities and the number of editions

\begin{tabular}{|l|l|l|l|}
\hline City & Number & City & Number \\
\hline Balaclava & 1 & Poltava & 6 \\
\hline Vinnytsia & 1 & Sevastopol & 1 \\
\hline Yelysavetgrad & 1 & Simferopol & 10 \\
\hline Zhytomyr & 6 & Sloviansk & 1 \\
\hline Kamianets-Podilskyi & 5 & Feodosia & 1 \\
\hline Katerynoslav & 12 & Kharkiv & 34 \\
\hline Kerch & 1 & Kherson & 8 \\
\hline Kyiv & 52 & Khorol & 1 \\
\hline Kremenchuk & 2 & Khorol & 1 \\
\hline Myrhorod & 1 & Chernihiv & 4 \\
\hline Odesa & 35 & Yalta & 5 \\
\hline
\end{tabular}

It is obvious that social communication of the mid XIX - early $\mathrm{XX}$ centuries from the modern one differed significantly, its forms and methods were others, (based on developments in historical studies of the journalism structure in the system of socio-communicative activities (history of communication, press, genres, separate editions, etc.)). O. Sedelnikova writes about this: "many public institutions of that time have not yet received independence and narrow subject specialization"13. So it may be fair to think that it's not entirely correct to apply a modern typology to the press of that time. This can be considered absolute in relation to virtually all social institutions of that time, except one medicine. Its communicative functions - both as a science and as a practical activity - were significantly different from others. There are several factors that make this clear. The first of these is related to the development of science - French explorer Paul Tannery in paper “L'histoire des sciences en Europe depuis le XIVe siècle jusqu'à 1900",

${ }^{12}$ Пирумова Н. М. Земская интеллигенция и ее роль в общественной борьбе до начала XX в. Москва : Наука, 1986. Ст. 118.

${ }^{13}$ Седельникова О. В. К определению типа дискурсивной организации русской журнальной периодики середины ХІХ в. Язык и культура. 2012. № 1. Ст. 37. 
assessing the development of science, emphasized: "in the face of bacteriological discoveries, the history of other natural sciences seems somewhat bleak in the last decades of the XIX century"14.

The second factor is the close connection, like no other industry, science and practice, which was supported by a high level of communication. The third factor is the readership of medical specialized editions was overwhelmingly composed of experts that influenced both the content and the level of the material presentation. The fourth factor is the number of publications. According to our calculations 186 editions were published in Naddniprianshchyna from the middle of the XIX - early $\mathrm{XX}$ centuries, which is not observed in any other sphere of human activity.

Specialized medical periodicals and serials referred to the press that: “a) was intended for people of the unique - biomedical - sphere, b) its content predominated information for scientific, popular scientific and practical areas studying normal and pathological processes in the body, various diseases, pathological conditions, methods of prevention and improvement of human health; c) it differed greatly by the pragmatic value and the specificity of purpose and served to satisfy the information interests of the target audience" ${ }^{\prime 15}$.

The process of saturation of the information space by specialized medical periodicals and continuing editions reflected the process of becoming and improving medicine - as science and practice, the process of expanding the network of medical institutions and clinics, systematization of medical education etc.

Saturation of the information space with the medical press is determined by three factors: frequency, intensity, duration of release.

Analysis of Chart 1 "Frequency of release" gives grounds to claim that the most significant filling of information space with specialized messages took place within one month. This includes items $1-6$, that is, daily, weekly, biweekly, monthly editions, as well as those, that are

${ }^{14}$ Tannery P. L'histoire des sciences en Europe depuis le XIVe siècle jusqu'à 1900. Revue d'histoire des sciences et de leurs applications. T. XVII. Paris, 1950. P. 123.

15 Садівничий В. О. Типологічна система спеціалізованої медичної преси (на прикладі видань Наддніпрянської України середини XIX - початку XX ст.). Журналістика : наук. зб. Київ : Інститут журналістики КНУ імені Тараса Шевченка, 2015. Вип. 14 (39). Ст. 59. 
published 1-4 times a week and 20 times a year. The total number of periodicals and continuing editions that have been published for one month is 101. Of these, 56 are newspapers and magazines that are published once a month.

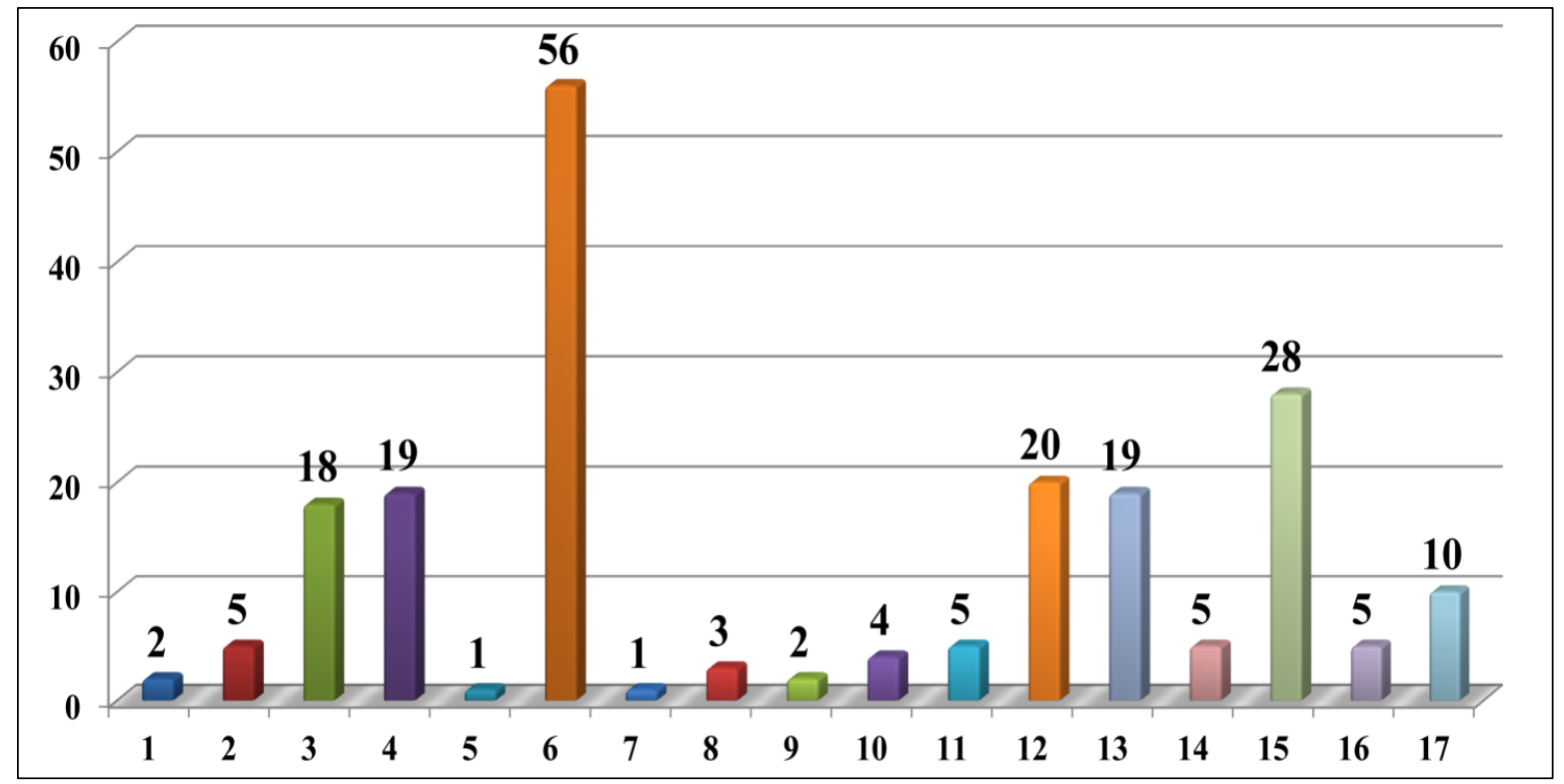

1 - daily; 2-1-4 times a week; 3 - weekly; 4 - two weeks; 5 - 20 times a year; 6 monthly; 7 - 10 times a year; 8 - two months; $9-2-4$ times a year; 10 - quarterly; 11 - six months; 12 - annual; 13 - without clear fixing of the release; 14 - one-day; 15 - release once; 16 - seasonal; 17 - frequency is not defined.

\section{Chart 1. Frequency of release}

The intensity of specialized press is important for the saturation of the information space - a fixation indicator of the number of editions that were published in a certain period of time, and the duration of their release. Generalized information of intensity by year is indicated by the curve, presented in Chart 2.

By 1882, the number of editions was growing rather gradually, 1-2 editions were added every year. The three peaks of growth, which can be clearly seen in the graph, are in 1894 (29 editions), 1901 (41 editions) and 1911 (65 editions). Since 1914, we have seen a decrease in saturation, when 10 editions were annually stopped and their number decreased to two in 1920. This decrease was first associated with the events of the First World War and then with the revolutions of 1917-1920. 


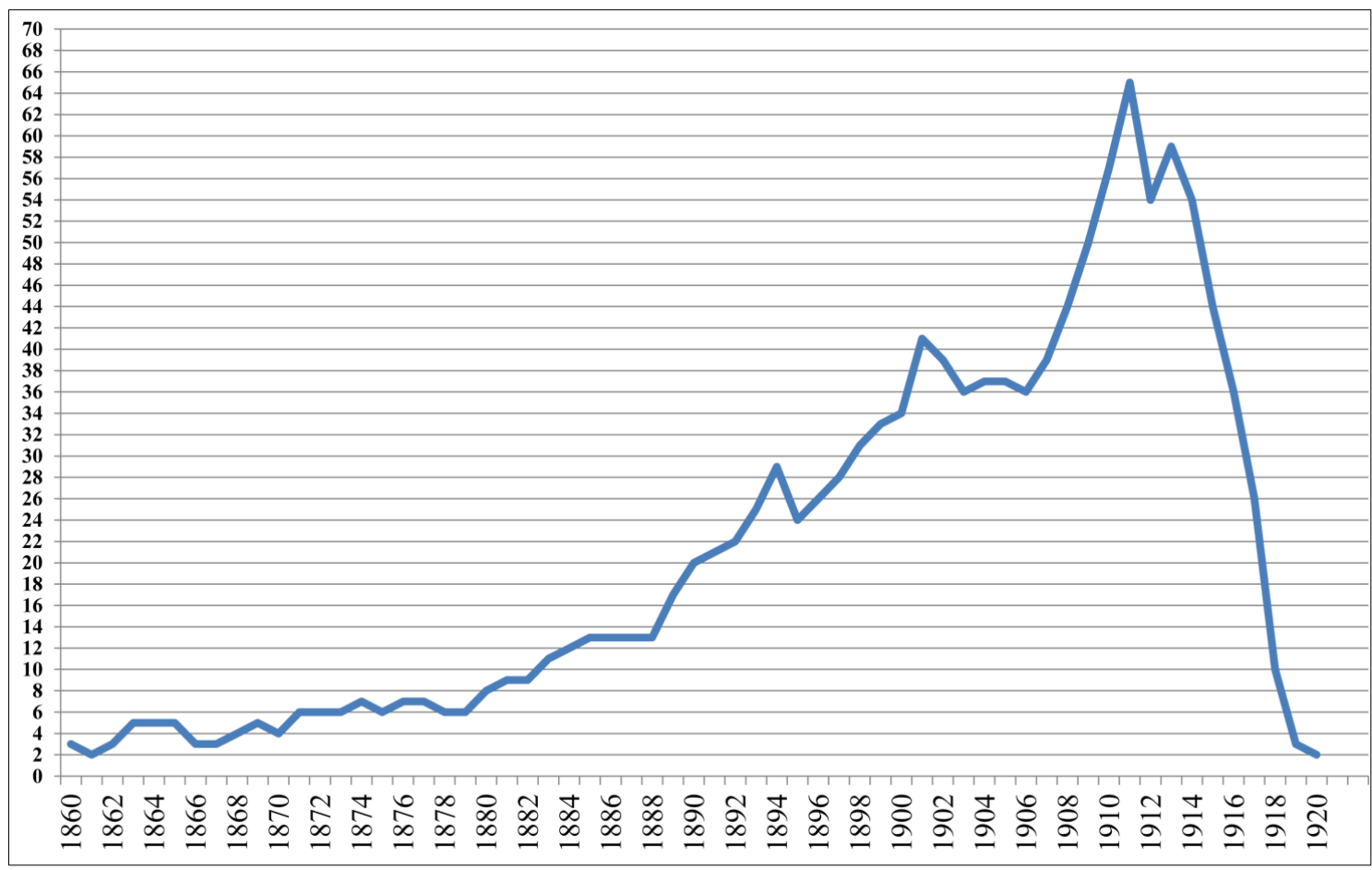

\section{Chart 2. Intensity of specialized press}

The general results of the analysis of the duration of medical press release in Naddniprianshchyna are presented in Chart 3.

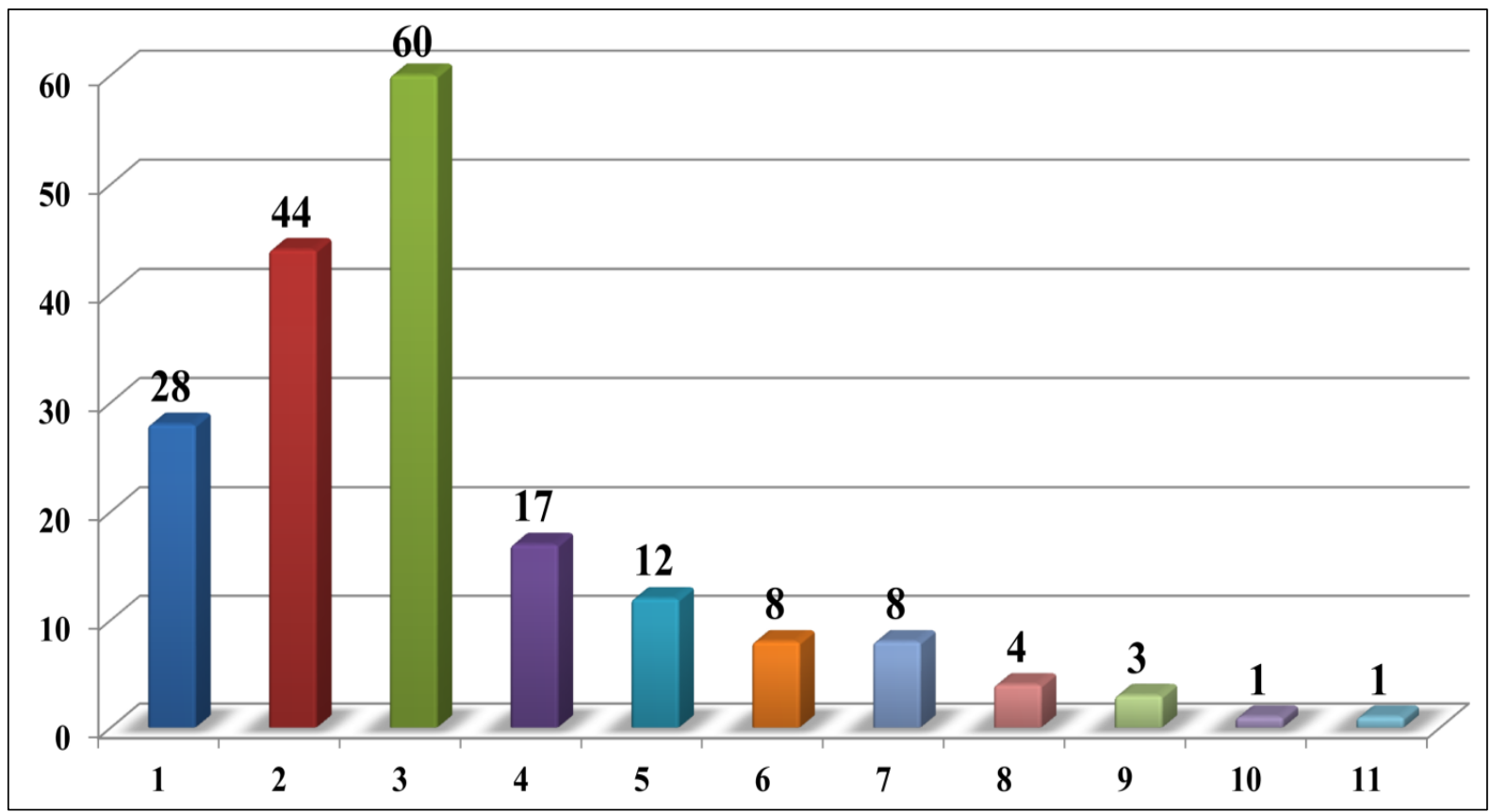

1 - release once; 2 - release to one year; $3-1-5$ years; $4-6-10$ years; $5-11-15$ years; $6-16-19$ years; $7-20-24$ years; $8-25-29$ years; $9-31-35$ years; $10-45$ years; $11-53$ years.

Chart 3. Duration of medical press release 


\section{Features of emergence and formation of medical periodicals in Naddniprianshchyna}

Specialized medical periodicals and continuing editions for their appearance in the information space of Naddniprianshchyna had some ground, formed by a number of significant factors.

One of the fundamental factors is the influence of scientific discoveries of the XVIII-XIX centuries, which created the foundation of medical and biological knowledge, contributed to their development and clinical application: "The remarkable achievements of natural science and philosophical idea, the creation of new scientific centers, the beginning of the widespread dissemination of natural science in society have contributed to an even more rapid rise of scientific knowledge, which took place in the second half of the XIX century, starting in the 60 's" 16 , S. Ruda characterizes that period.

F. Engels called the "three great discoveries" among the most significant natural achievements of the late XVIII and first half of the XIX centuries, which were further decisive for the development of dialectical views on nature and the development of medicine. These are the theory of the cellular structure of living organisms, the law of energy conservation and transformation, and evolutionary doctrine ${ }^{17}$, which explained all the basic processes in nature by natural causes.

These processes led to the accumulation and systematization of knowledge about the laws of nature, an integral part of which is the human body. Their accumulation has always changed the formation of the scientific picture of the world, introducing and justifying new laws of development.

Another factor is the rise of medical practice. Along with the development of science, the capitalization of society influenced him from the second half of the XIX century. This capitalization had an impact on the Russian Empire.

\footnotetext{
${ }^{16}$ Руда С. П. Становлення мікробіологічної науки в Україні: гносеологічні та інституціональні аспекти : автореф. дис. ... канд. істор. наук : 07.00.07. Київ, 2001. 20 с. Ст. 1.

17 Энгельс Ф. Из истории науки. Диалектика природьл. Москва : Госполитиздат, 1953. Ст. 155-156.
} 
The development of both industrial production and agriculture prompted doctors to survey the working conditions and health of workers in industrial enterprises and agricultural industries where mechanization was gaining ground. 90's of the XIX century characterized by the development of sanitation and preventive medicine. In view of this, the posts of county sanitary doctors are being introduced in the counties.

Initial reforms have contributed to the steady increase a number of newspapers and magazines: the introduction of the university charter in 1863 , the county and judicial reforms in 1864 , the educational reform in $1863-64$, the urban reform in 1870, and others. On the basis of reforms, a reorganization of the local government system took place: the existing feudal basis was replaced by decentralization and involvement in government. The first specialized medical edition introduced by a local government is "Trudyi postoyannoy meditsinskoy komissii pri Poltavskoy gubernskoy zemskoy uprave"/"Proceedings of the Standing Medical Commission at the Poltava Provincial County Council" (1869).

"Vrachebno-sanitarnyie hroniki"/"Medical and Sanitary Chronicles", which was published in virtually all provinces, addressed the employees of county medicine, reported on the activities of the county administration in the sphere of public health. They submitted resolutions of the provincial county assembly, notes about the surveillance of epidemic diseases and the geography of their distribution, reports about the activity of medical districts, vaccinations, medical reports (often in the form of tables), protocols of meetings of county doctors' congresses, programs of their activities, reviews of county medical press, reprints of foreign periodicals, correspondence, announcements.

Among other things, the medicine contribution to the state development was characterized by the accumulation and synthesis of empirical knowledge about human diseases; new discoveries in the sphere of biomedical sciences; the development and emergence of new clinical disciplines; development of vaccines for the treatment and prevention of fatal diseases; study of occupational diseases and establishment of factory hygiene, directly related to the industry development; formation of social, teenage, communal hygiene, etc.; establishment of preventive medicine, etc. 
The development of the business of treatment people, which had resolved by counties from the second half of the XIX century, could not be successful without the training of medical staff. Accordingly, the state developed existing ones and created new medical faculties at universities.

Medical faculties, playing a significant role in shaping the professional environment, also became centers where people from one professional community met. Of course, they varied on a number of features, such as education, intellectual level, social status, property status, age, and so on. But they were united by their desire to exchange theoretical and practical knowledge.

Universities had a solid printing base at the time. Accordingly, cities Kyiv, Kharkiv, Odesa - where medical faculties operated at universities, first and foremost became centers of advent of the specialized press.

The medical faculties also formed the professional environment that gave birth to both the producers of specialized information, its disseminators in the person of editors and publishers, as well as recipients, professional consumers.

End of XIX - beginning of XX century is also characterized by the growth of scientific societies, special commissions and other public health organizations. They included not only doctors but also other intellectuals. This testify to the consolidating role of physicians as representatives of the most educated intellectuals, in uniting citizens to protect people's interests and create conditions for self-fulfillment. This exacerbated the impact on the society of medical knowledge. Accordingly, a social order for specialized information emerged and the task of storing and transmitting it was set up.

According to the actual data that O. Tsiborovskyi points out, "The first scientific society of doctors in the country was established in Kherson in 1784 on the initiative of D. S. Samoilovych. Soon... the Society of Kiev doctors was founded in 1840, the Society of Odesa doctors - in 1849, The Society of Volyn, Podil, Kharkiv Medical Societies respectively in 1859, 1860 and $1861 \%$. In general, there were scientific societies, charitable

${ }^{18}$ Ціборовський О. М. Наукове і практичне значення досліджень 3 історії української медицини. Україна. Здоров'я нащії. 2012. № 1 (21). Ст. 169. 
medical organizations, and professional medical associations in the medical spheres.

Speaking about the prerequisites, it is necessary to refer to the right opinion of S. Makhonina: "with the development of the journalism system at the turn of the XIX and XX centuries there are a number of different types of editions that not only reflect the development of ... culture, but also become indicators of the cultural level of social development. First of all, these are editions on various issues of literature and art, popular science and some others"19.

Analysis of the medical press of Naddniprianshchyna in the mid XIX - early XX centuries gives us reason to argue that editions are universal-themed and mono-themed in terms of thematic and content characteristics. Accordingly, they are divided into: a) publications in the spheres of therapy, surgery, dentistry, obstetrics and gynecology, psychiatry and neurology, ophthalmology, pharmacy, radiology, skin and venereal diseases, pediatrics, physiotherapy, balneology, disaster medicine, military medicine, veterinary medicine; b) editions in theoretical, practical and evidential medicine; c) medical and veterinary bacteriology; d) epidemiology; e) alternative medicine - homeopathy; e) lifestyle and nutrition - hygiene, vegetarianism; e) cross-industry editions; g) advertising editions.

Editions in various spheres of medicine have taken a significant place: ophthalmology, neurology, psychiatry, pharmacy. A number of factors contributed to the emergence of these journals, among which the development of science, the emergence of relevant departments at medical institutes, the study of various diseases, the change of attitude to specific patients, etc.

Sectoral editions were published 49: newspapers -7 , magazines by content -22 , magazines by form -20 .

The distribution of editions in certain spheres of medicine was very uneven. If you take the provinces, the situation looks like this:

${ }^{19}$ Махонина С. Я. История русской журналистики начала XX века : учебн. пособ. Москва : Флинта ; Наука, 2004. URL: http://evartist.narod.ru/textl/84htm (дата звернення: 18.02.2020). 
Kherson - 19; Kharkiv - 16; Kyiv - 12; Tavriya - 9; Katerynoslav - 6; Podil - 3; Volyn - 2; Poltava - 1 .

By purpose (based on our research, the basis of which was the texts topic analysis, especially editorials, as well as the analysis of stated concepts), specialized medical periodicals and continuing editions are divided as follows: general medical direction, sectoral, applied, advertising-information, scientific, scientific-popular, popular, officialdocumentary, chronic-documentary, statistical, reference.

The most numerous by purpose is the edition of general medical direction.

Scientific publications include "Zapiski..."/"Notes..." of medical societies and educational institutions, "Protokolyi..."/"Protocols..." and "Trudyi..."/"Labor..." of medical societies, and others - total 59.

The publications stood out for the high scientific level which was proved by important conclusions and formulated scientific approach. According to functionality, the texts divided into reviews, methodological, empiric and factual, theoretical, explanatory, supplementary and mixed types. Every paper included author's opinion and a certain analysis of the performed work. The prevailing way of information representation is the esoteric one, according to which ideas, theories, conclusions, etc. were meant for well-informed people, i.e. understandable only for specialists. The main areas of theoretical and academic content included: insufficiently studied and new diseases for that time; original methods of treating them; theoretical and practical researches which concerned practicing physicians, privat-docents, professors and enabled them to follow the development of national and international medical and biological science. A separate place was given to abstracts of mostly practical and theoretical content from foreign periodicals, books, serials.

The group of official and documentary editions is formed by "Bulletins ...", "Vedomosti...", “Reviews...", "Information..." and "Chronicles...". The founders or publishers were provincial and county administrations, provincial county sanitary administrations, sanitary and medical bureaus of public health departments of city administrations, 
sanitary departments of county and city administrations, counties, city sanitary stations, city public administrations.

The main function of official publications is to convey professional information to meet the needs of its target audience. It is the function that determines the subject-matter direction - to submit professional information of a utilitarian nature. These include: circulars from the Department of the Interior's Medical Department, official notices and orders from the Provincial County Administration, journals and minutes of various meetings, reports on medical trips of doctors, diagnostic studies, forms of various reports, changes in the cast of county medical staff, experience of health services work abroad, journals of veterinary councils meetings, review of county medical press, reprints from Russian and foreign periodicals, occupational health, the life and education of doctors and their assistants, information about orphans and abandoned children brought up at the expense of county self-government, activity of Pasteur stations, arrangement of shelters, organization of medical and sanitary assistance to refugees and work of school doctors, etc.

In substantiating the history, theory, and development of the specialized information space, we emphasize the particular importance of agents of scientific and practical activity, who were involved in the production and consumption of information, in understanding the need to disseminate knowledge and obtain information from others. Agents in the biomedical sphere were: students, associate professors and professors of medical faculties of three universities in Naddniprianshchyna (Kyiv, Kharkiv, Odesa) and Kharkiv Veterinary Institute; employees of research institutes - Bacteriological institute of Kharkov medical society, Odesa bacteriological station, Kyiv Bacteriological Institute, veterinary bacteriological and sanitary laboratories, etc.; members of scientific medical societies and other public associations of biomedical and veterinary directions, heads of departments of county and medical services of cities.

The audience was not only the consumer of the information that was being offered, but also evaluated it, took an active part in the production, influenced the thematic policy. That is, we have an audience with a 
specific interest structure. We can say that the editions were intended for the mass reader or for a specialized audience by distinguishing the auditory features of the analyzed press.

According to the language: Ukrainian was published 9, Polish - 2, Russian - 175. The Ukrainian- language editions were: Kyiv - 6, Poltava - 2,

Khotyn -1 . In terms of frequency, these were: bi-weekly -3 , monthly -4 , indefinitely -1 .

\section{CONCLUSIONS}

The socio-communicative aspects of specialized health information differed significantly from others. This is clearly demonstrated by three factors. The first is related to the development of science; the second is a close, inseparable link between science and practice; the third - a readership that was actually entirely made up of experts.

The emergence of new, thematic-meaningful transformation of existing specialized medical periodicals and continuing editions, growth of their activity, implementation of editorial programs contributed to the expansion of the segment of information products and services in the general structure of the national information space, filling it with highquality specialized information. The main focus of the specialized medical information space is to address the challenges of the institutional health care system by ensuring the communicative functions of the sphere. The specialized medical information space of Naddniprianshchyna in the second half of the XIX - beginning of the XX centuries characterized by the development of social institutions (higher education institutions, scientific and other societies, research organizations, medical institutions); by saturation of the generated and reproduced medical knowledge; by presence of professional communication agents; by corporate using; by a community of typological features whose properties are defined by information infrastructure; by the fact that there are specialized medical periodicals and continuing editions.

Focusing on specialists and the mass reader, the medical press more dynamically and comprehensively showed the development of the medical business at that time took care of improving the skills of specialists, took 
care of protecting the interests of health workers, promoting a healthy lifestyle.

\section{SUMMARY}

The history and principles of formation of specialized medical space on the example of Naddniprianshchyna are investigated. In the period from 1860 to 1920,186 specialized medical periodicals and continuing editions were published in 9 provinces (Volyn, Katerynoslav, Kyiv, Podil, Poltava, Tavriy, Kharkiv, Kherson, Chernihiv). Research result: the specialized medical information space of Naddniprianshchyna in the second half of the XIX - beginning of the XX centuries characterized by the development of social institutions (higher education institutions, scientific and other societies, research organizations, medical institutions); richness of the generated and reproductive medical knowledge; professional communication agents (medical scientists, medical practitioners and clinicians, nursing staff, students); corporate using; a community of typological features whose properties are defined by information infrastructure; the fact that there are specialized medical periodicals and continuing editions. The main focus of the specialized medical information space is to address the challenges of the institutional health care system by ensuring the communicative functions of the area.

\section{REFERENCES}

1. Кононович В. Г. Визначення інформаційного поля з позицій інформаційної безпеки. “АВІА-2011”: Матеріали Хміжнародної науково-технічної конференції. Секція 2 - Інформаційна безпека. Київ : НАУ, 2011. С. 2.34-2.37.

2. Плескач В. Л., Затоноцька Т.Г. Інформаційні системи i технології на підприємствах : підручн. Київ : Знання, 2011. 718 с. URL: http://pidruchniki.com/1350052747708/informatika/ponyattya_informatsiyno go_prostoru (дата звернення: 15.02.2020).

3. Медицинская периодическкая печать. Большая медищинская эниңиклопедия. Москва : Советская энциклопедия, 1980. Т. 14. Ст. 377. 
4. Медицина. Большая медицинская энциклопедия. Москва : Советская энциклопедия, 1980. Т. 14. Ст. 3.

5. Соціально-філософські та етичні проблеми медицини : навч. посіб. ; за заг. ред. А. П. Алексеєнко, В. М. Лісового. Харків : Колегіум, 2010. 340 c.

6. Гомеопатия. Большая медицинская энщииклопедия. - Москва : Советская энциклопедия, 1977. Т. 6. С. 307-309.

7. Соціально-філософські та етичні проблеми медицини : навч. посіб. ; за заг. ред. А. П. Алексеєнко, В. М. Лісового. Харків : Колегіум, 2010. 340 с.

8. Садівничий В. О. Становлення вітчизняного інформаційного простору в сегменті медичної преси наддніпрянської України XIX початку XX століть: типологія, функціонально-змістові особливості, комунікативно-прагматичні складники : дис. ... д-ра наук із соц. комунік : 27.00.04. Київ, 2015. 481 с.

9. ДСТУ 7152:2010. Видання. Основні види: Терміни та визначення. [Чинний від 1996-01-01]. Вид. офіц. Київ, 1995. 48 с. (Інформація та документація).

10. Семистяга Т. Видавничо-поліграфічна галузь України: динаміка й проблеми розвитку (2002-2004 роки). Друкарство. 2005. № 2. С. 5-8.

11. Садівничий В. "Відродження розпочинається із гласності..." : (Медична преса Наддніпрянської України середини XIX - початку XX ст.) : монографія. Дніпропетровськ : Середняк Т. К., 2015. 360 с.

12. Пирумова Н. М. Земская интеллигенция и ее роль в общественной борьбе до начала ХХ в. Москва : Наука, 1986. 268 с.

13. Седельникова О. В. К определению типа дискурсивной организации русской журнальной периодики середины XIX в. Язык $u$ культура. 2012. № 1. C. 36-42.

14. Tannery P. L'histoire des sciences en Europe depuis le XIVe siècle jusqu'à 1900. Revue d'histoire des sciences et de leurs applications. T. XVII. Paris, 1950. P. 123-434.

15. Садівничий В. О. Типологічна система спеціалізованої медичної преси (на прикладі видань Наддніпрянської України 
середини XIX - початку XX ст.). Журналістика : наук. зб. Київ : Інститут журналістики КНУ імені Тараса Шевченка, 2015. Вип. 14 (39). С. 32-45.

16. Руда С. П. Становлення мікробіологічної науки в Україні: гносеологічні та інституціональні аспекти : автореф. дис. ... канд. істор. наук : 07.00.07. Київ, 2001. 20 с.

17. Энгельс Ф. Из истории науки. Диалектика природыл. Москва : Госполитиздат, 1953. С. 145-158.

18. Ціборовський О. М. Наукове i практичне значення досліджень 3 історії української медицини. Україна. Здоров'я нації. 2012. № 1 (21). С. 168-173.

19. Махонина С. Я. История русской журналистики начала XX века : учебн. пособ. Москва : Флинта ; Наука, 2004. URL: http://evartist.narod.ru/textl/84htm (дата звернення: 18.02.2020).

\section{Information about the author: Sadivnychyi V. O.,}

D.Sc. in Social Communications, Associate Professor at the Department of Journalism and Philology, Sumy State University 2, Rymsky-Korsakov str., Sumy, 40007, Ukraine 